\title{
Local Knowledge As A Result Of Informal Education For Community-Based Conservation In Pacitan
}

\author{
Mustangin \\ Department of Non Formal Education, Faculty of Education \\ Indonesia University of Education, Bandung, West Java, Indonesia \\ Email Address: mustangin1992@gmail.com
}

\begin{abstract}
Farmers have local knowledge to manage their farms which are located in each region. Local knowledge is a result of informal education process that is important for farmers' daily life. This research was conducted to find out few things related to local knowledge forms, the importance of local knowledge, and the role of local knowledge in conservation activities. This study used qualitative approach with case study. This research used interview and document study as data collection method. Research findings showed that the farmers in Pacitan have several forms of local knowledge: 1) Land for the community concept; (2) Mongso system. Second is the importance of local knowledge; Land as a source of life. Mongso is as a sign of the beginning season for agricultural activities. Third, the role of knowledge in conservation activities as follows. (1) Local knowledge as basis to start the activity; (2) A viewpoint of public awareness stage about land; (3) Mongso Knowledge used in inveiglement stage; (4) Using local knowledge as one of determining meter of successful program.
\end{abstract}

Keywords: Local Knowledge, Community Development, Soil Conservation

\section{Introduction}

Farmers have knowledge that is used to manage farming activities in their daily life. The concept of local know ledge may be intuitive: people know a great deal about the places where they live.[14] Local knowledge about how to cultivate existed farmland is a knowledge which is told from generations in society, particularly in societies in Pacitan, East Java. Local knowledge that is existed in today's society is the result of the education that is taught by parents or ancestors of the community itself. Local know ledge is well developed, where the majority of people's lives in the area is as a farmer. Citizen's dependency on agriculture is high, it can be seen on the daily activities, therefore, having knowledge of how to cultivate farmland becoming mandatory for farmers in Jetis Lor village, Pacitan.

Based on preliminary research, data shows that in 2002 citizen in Pacitan implemented soil conservation program which was conducted with Institute for Rural Technology Development (Lembaga Pengembangan Teknologi Pedesaan - LPTP ). The implementation of conservation programs undertaken in the village Jetis Lor is a community-based conservation. Community-based conservation is conservation community involvement as one of the executors or the main actor in implementing conservation programs. One of the activities in program implementation is to utilize all the potential possessed by the public, including local knowledge potential. The knowledge of weather patterns and droughts is therefore an important aspect in the planning and management of agriculture and water resource systems. [13]

There is no general definition about local know ledge as a system. Local know ledge systems that exist in the community are indigenous knowledge, indigenous knowledge systems and traditional know ledge systems. [1] Local Knowledge Mathias is the knowledge that is developed based on the experience that has been tested its use over the centuries, has been adapted to the local culture and environment as well as dynamic. [2]

It can be concluded that local knowledge in this study is the knowledge as a kind of order or local people's perspectives are used in various purpose in life. Local knowledge that existed in society today is a legacy of knowledge that deserves to be appreciated as well preserved because it has a special meaning 
for the community. Local know ledge is more important to adaptation actions than is commonly, it is more specific to the geographical and cultural features of place. [11] The successful of land conservation programs in Jetis Lor village cannot be separated from the role of local knowledge. Soil conservation program in Jetis Lor is one of community empowerment programs that is ran to engage the community potential, one of which is the potential of the knowledge society that is local knowledge. So this research will reveal community's local knowledge and its contribution to community-based conservation program.

\section{Research Methods}

This study used a qualitative approach, because this research will reveal details about the local know ledge of community and its contribution to conservation programs. In addition, this study also used case study, because it will reveal the specific cases related to local knowledge. This research was conducted in Jetis Lor, District Nawangan, Pacitan. Jetis Lor is one of the villages that were targeted as community empowerment program which is soil conservation movement by us ing successful communitybased approach. Through the soil conservation program, Jetis Lor has successfully received the award as a National Level Climate Village from ministry of the environment because they are successful in adaptation and mitigation of climate change.

Data source in this study distinguished of the primary data sources and secondary data sources. Sources of primary data obtained through interviews with informants and observations. While the secondary data source obtained through documentation and official archives that can support the research. The procedure of collecting data in this research used some techniques include:

- Interview: Researchers conducted interviews with residents in Jetis Lor village who was directly involved in soil conservation activities villages of Farmers Conservation Group chairman, Member of Farmer Conservation Group, and field facilitators who act as the responsible program from Institute for Rural Technology Development (Lembaga Pengembangan Teknologi Pedesaan - LPTP ). The data collection process is to interview more than one informant is done to obtain valid data. Researcher used in-depth interview techniques in a variety of situations. It aimed to create a familiar atmosphere between researchers and informants. Familiarity is done to get the data that has depth and detail. In the interview process, listening, writing, and recording were involved.

- Observation: Researchers collected data directly to farmland to make observations by observing the natural conditions of society, the pattern of the work done by the community Jetis Lor Nawangan District of Pacitan. Observations conducted by researchers was used to support data on forms of local knowledge.

- Study Documents: Researchers conducted a study document on the document reports of Soil Conservation Plan Village. These document studies were done to strengthen data interview. This is done by the researchers to support the data on the forms of local knowledge.

The analysis technique is the first data reduction, both doing data presentation, the three withdrawals initial conclusions based on the findings of the data, verify data and final conclusion. Checking the validity of the data is done by triangulation of sources. That is by checking any data obtained through indepth interviews and then cross-checked (cross check) to the informant different. If the same data obtained between each informant, then the data is valid and in accordance with the ground reality.

\section{Results And Discussion}

\subsection{Local Knowledge as A Result of Informal Education}

Forms of local knowledge in the society including the philosophy or view towards land itself for the people Jetis Lor. For Jetis Lor people, land is considered as the main source of income. Most people are even willing to spend each day to cultivate agricultural land which will be handed to the next generation. So, it makes the ideas within the community that the land should be treated from the things that threaten the loss of function of the land itself. Community views on the philosophy of land called as local 
know ledge which is expressed by Johnson as set of knowledge that was created by a group of people from generation to generation that lived together and in harmony with nature, this kind of know ledge to grow and thrive in the local scope, adjusting to the circumstances and needs of the community [3]. The importance of keeping the land that has been owned taught by parents to the next generation so that they do not neglect their parents' heritage land, so that their children were able to keep their land for a better life.

Philosophy of how importance land becomes the main lesson material in education in the family and in the community for next generations. Many parents teach their children about the importance of keeping the soil directly, including how to preserve the land owned by the company. Most of them do not attend school, majoring in agriculture in particular, but the study of agriculture they get from their parents. The youths and even children in Jetis Lor has a habit to accompany the ir parents to farm on holidays. Furthermore, the parents teach directly how to farm or treat agricultural land in accordance with its local knowledge. In addition, knowledge of agricultural land as well as through regular meetings of farmers who are members of farmer groups. This knowledge transfer is then referred to informal education.

Community perceptions of philosophy called as local knowledge. This affects the public mindset in treating the soil. Knowledge of traeting for the land must also be learned by the younger generation. Knowledge transfer is done with non-formal and informal education. The importance of teaching how to treat land by the parents to their children is taught directly. Kids in Jetis Lor are accustomed to follow their parents into the fields or rice paddies. From there, usually parents teach directly to her. Transfer of knowledge is then referred to informal education.

Informal education is education due to deliberate on the part of educators (learning resources) to assist or direct certain learners to gain learning experience, this education can be an individual who performed in the family (educators natural) parents and also do through groups activities that have a common interest [4]. In-formal Education concrete, the examples such as education that occurs as a corollary of the functions of the family, the media, religious events, campaigns, participation in organized groups and so on.

The next form of local knowledge is the right way to start planting. One of the activities in the life of farmers is planting activities. Farmers have their own benchmark time to start new agricultural activities benchmark when it became known as the Mongso System.

Mongso system is also called as season in Javanese culture which is adapted from the Javanese calendar. One of the uses of Mongso is to know the start time of planting. There is common way used by the public to mark Mongso planting (planting season arrives). One way to see the arrival of Mongso Cropping is a natural condition, but also based on the behavior of animals, such as the emergence of worms. Farming communities have the knowledge to support the farming activities on natural conditions, know ledge of the behavior of animals; people have the knowledge about the concept of time to determine the time, as well as knowledge of plants [6]. Mongso can also be adjusted with calendars that are viral in the community.

Informal education about Mongso system, especially for planting Mongso, will be told through stories by parents every day while relaxing or a small discussion about the farm. Then by his son followed and practiced alone. The study then will generate knowledge, knowledge that is based on custom developed in the community. In addition to learning about Mongso can use calendars that are viral in the community. Many calendar which lists about Mongso, from the calendar that it can be seen how the often Mongso happened. Along with development uncertain seasons. For example, the rainy season sometimes come prematurely. However, mongso are still used. The different is how to mark it by looking at the first rain in a period of one year. Informal education done to citizen system related Mongso as a learning process in everyday life, there are unstructured, disorganized, are sporadic, learning is spontaneous, and usually intended to resolve / complete an assignment, or goals intrinsic others [7]. It can be seen clearly that there is a purpose comprehending of when begin to plant. 


\subsection{Local Knowlede for Empowerment Community Process}

Soil and Mongso system have a special meaning for the people. That what makes people not change these provisions until today. Land has a special meaning in people's lives. Soil treated separately in the community. Therefore, the soil should be protected from threats such as erosion. Land is the most basic needs substantial presence as a symbol of local communities that are magical and sacred [1].

In addition to the perspective of the soil, the meaning in mongso system is also considered important to be applied is used as a marker to guide the process of planting. People believe that by using a benchmark system Mongso will get good results. Dynamism of knowledge is as a process of influencing on the pattern of natural resource management, especially of local farming systems [3]. Often the practice of local agricultural systems can provide an idea of potential in the use and management of resources in a sustainable manner. Mongso system as one of the local agricultural systems can overcome the problem of failure in agricultural activities. Mongso system is an ancient culture to address issues related to crop failure or results obtained by local communities, so that local knowledge can give an idea of the potential for solving problems related to agriculture.

The local knowledge that has been embedded in the community can be applied to help the process of community-based conservation. Community-based conservation is the most important tool and has been recently used globally in natural resource management especially in managing the sustainability of the protected area, restoring ecosystems and reducing poverty in rural areas [13]. Conservation program conducted in Jetis Lor implemented either by utilizing the experience of the community, the experience may be related to local knowledge.

Community views on how importance of land means that the land is the source of life. The public view of the material used to sensitize the public. Based on the view is then LPTP visualize the impacts that occur on land owned by the community if it is not carried out to conservation. How that is done is during heavy rains to invite people to the river. LPTP together people take water in bottles. The bottle was allowed to stand so that no soil sediment in the water. Then the land was taken and weighed. After that LPTP with the community summaries of the scales with the area of land owned after the results were known, the public was asked to conclude, in order to get the land owned by the community will be eroded erosion, that's concluded by the public.

At inveiglement stage, public are given freedom to carry out conservation activities based on what their habits. This can be seen from using Mongso system by society in planting. During the planting activities, people use Mongso to start planting. The role of local knowledge is public knowledge program that departs from the knowledge own by the community will foster public acceptance of the program so as expected. Conservation activities are consistent with that expected by society.

Local knowledge society is used as a base to start the program. The program is conducted by community-based can also be regarded as people's empowerment. While community empowerment program involved elements of the community as main actor. If you want to engage in a process of community development (empowerment) then steps must be done on the basis of local knowledge such as this, and in this case the local community, therefore the agent reformer cannot claim ourselves experts [8].

Farmers in Jetis Lor consider land as a precious treasure for himself and for the next generation. Land becomes importance for people there. Many people who claim that they will participate in conservation programs to preserve the land for them is the most valuable asset. The facilitator invites the public to see the condition of the land and told people to calculate the area of land he owned. From the results, there is any change in its soil eroded by the erosion when it rains. The facilitator then invites the public to take precautions against erosion, it was agreed program of community-based conservation.

Stage awareness in community-based conservation program is very important it relates to the readiness of society to be fully involved in the implementation of the program. The ir meaning to the ground enables the facilitators to sensitize the public to be involved in the program. Because one way to achieve empowerment or community programs is ranging from awareness of the needs and potential of the community [9]. 
Knowledge about the time of planting in this case is associated with Mongso system. Where such knowledge entrenched in people's lives Jetis Lor. So the system Mongso still used in soil conservation activities. Mongso system is used as local knowledge related to the stages of deception.

Mongso is a benchmark in the community and was already a decision in the life of society. At this stage, people are given the power to carry out conservation activities. During the planting in one soil conservation activities, the public can use Mongso to start the planting. The facilitator is only suggested for planting trees that have conservation value that supports programs designed together without changing the values that have been adopted by the local community. Kusumahadi stated that efforts at community empowerment consists of several components of one of those so-called empowerment, which develops the potential and ability of people to take part in development [10]. So inveiglement activity is done to increase the potential that has been owned by the public without ruling out the orders that have been owned by the public.

The role of local knowledge the next is to foster public acceptance of the program. Based on the findings in these conservation activities in accordance with what is expected of society. The use of local know ledge may determine the success of a program in which it is built on the principle of, by, and for the community. Here is an illustration of the relationship between local knowledge and community-based conservation.

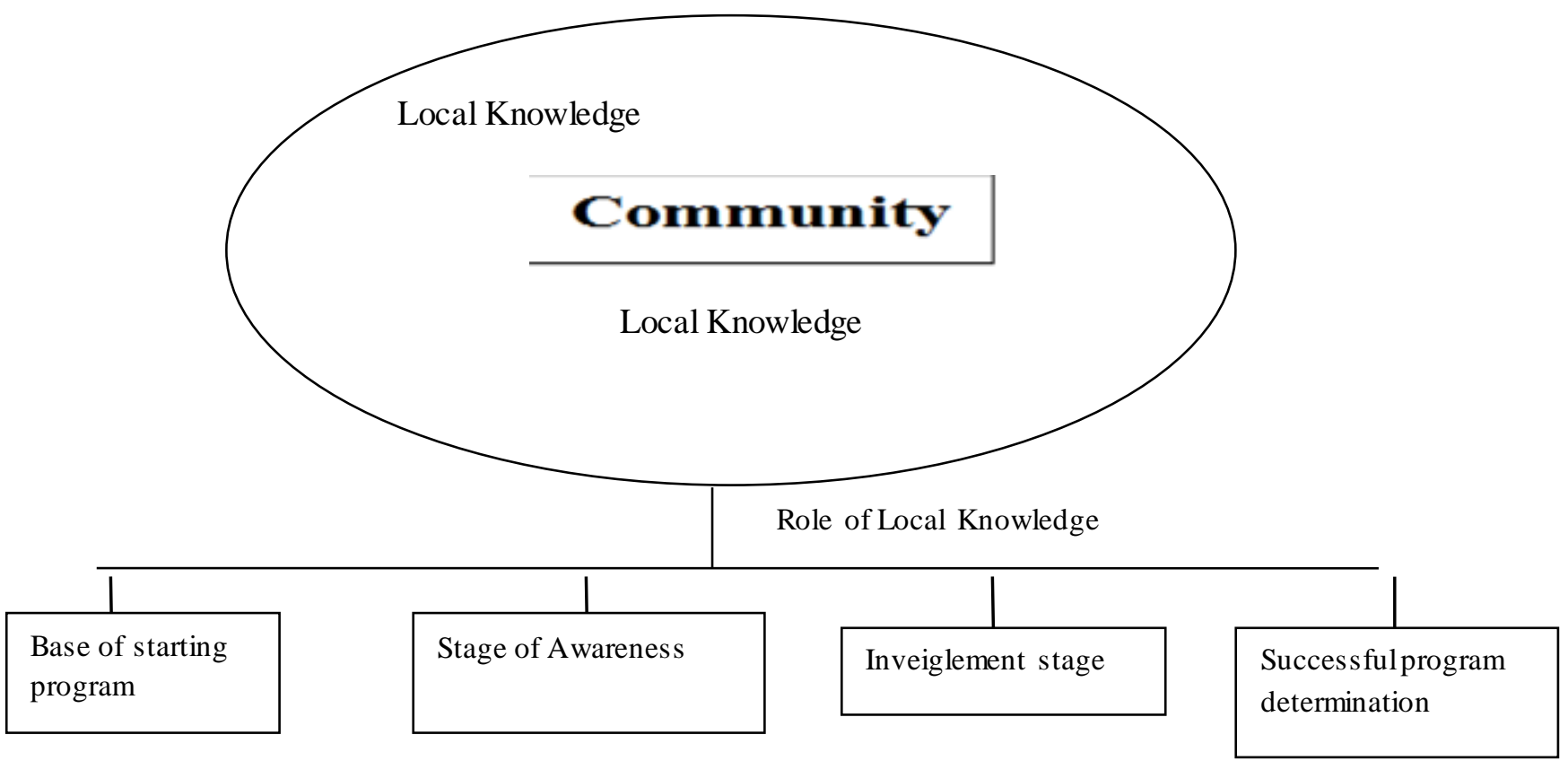

Fig. 1: The Ilustration local knowledge and community based conservation

Community-based conservation programs implemented in Jetis Lor is one of the successful programs, one key to success is to do is to involve community participation. This can be evidenced from the implementation of the programs implemented by the facilitators and local communities.

\section{Conclusion}

Based on field findings that were described in the results and discussion, it can be concluded on each research topic, including forms of local knowledge, the importance of local knowledge, and the role of local knowledge in community development activities. First, based on the forms of local knowledge. Based on data known that the form of local knowledge society in Jetis Lor is divided into two, including the following: 
- The Society for the land, that the land has a special meaning in the life of society, land is a source of income and the source of life that must be maintained in order not washed away by erosion. Local knowledge transfer related to land through informal education done by individuals through family education and collectively through farmers' groups.

- Jetis Lor society has to start planting season sign called mongso. Mongso based on the knowledge possessed by the people related to the phenomena of nature, animal behavior, as well as the ability to calculate to determine the timing and choice of plants planted existing mongso supported by the calendar in the community.

Second, local knowledge has its own meaning. Land has significance as a source of income, so that the soil is the source of life for people in Jetis Lor. Besides, the significance of mongso can be seen from mongso usability based on community trust. By following the rules mongso people believe that agricultural products are obtained or harvested will be the maximum.

Third Local knowledge has a role in community development activities of local know ledge are used as the basis start the program as a form of valuing local knowledge. Their views on land as a source of life is used in order to solve the problem of awareness in society. At the community conservation program is given the power to use the community-owned ways including using mongso as one of the knowledge contained in the community in conducting investment activities. Local knowledge can also determine the success of a program in which it is built on the principle of, by, and for the community so that the program as expected by the public.

\section{Acknowledment}

This research was conducted for the good cooperation between researchers with local governments in Jetis Lor Village and facilitator from Institute Rural Technology Development (Lembaga Pengembangan Teknologi Pedesaan - LPTP ). Researchers also thanked Education Fund Management Institution has provided assistance for the writing of this paper. Researchers also thank all the team who has helped in data collection in the field.

\section{References}

[1] K. Adimihardja, 2008. Dinamika Budaya Lokal. Bandung, CV. Indra Prahasta and LBPB, 2008, pp. 1-10

[2] S. Sunariyati, "Pengetahuan Lokal Masyarakat Suku Dayak Ngaju dalam Memanfaatkan Tumbuhan Sebagai Bahan Kajian Pengintegrasian Etnobotani pada Kurikulum SD di Wilayah Pedalaman, " Dr. Dissertation, School Of Postgraduate, State University Of Malang, Malang, Indonesia, 2010

[3] Sunaryo \& L. Joshi, Bahan Ajar Agroforestri 7: Peranan Pengetahuan Ekologi Lokal dalam Sistem Agroforestri. Bogor, World Agroforestry Centre (ICRAF), 2003, pp. 01-10

[4] Supriyono, 2012. "Menggagas Interkoneksi Antar Jalur Pendidikan: Sinergi Pendidikan Sekolah Dan Pendidikan Luar Sekolah Dalam Pembangunan Pendidikan Nasional, " Presented at the Inauguration of Professor in concentrations of School Education in the Faculty of Education, State University of Malang, Malang, October 10, 2012

[5] S. Faisal, Pendidikan Luar Sekolah Di Dalam Sistem Pendidikan dan Pembangunan Nasional. Surabaya, Usaha Nasional, 1981, pp. 55-70

[6] Koentjaraningrat, Pengantar Ilmu Antropologi. Jakarta, Rineka Cipta, 1979, pp. 360-373

[7] A. J. Doornbos, "Work Practice, Learning Worker Characteristics and Informal Learning," Presented at Academy of Human Resource Development International Conference (AHRD), Amerika, June 6, 2004

[8] J. Ife and F. Tesoriero, Community Development: Alternatif Pengembangan Masyarakat Di Era Globalisasi. Yogyakarta, Pustaka Pelajar, 2008, pp. 230-255

[9] O. M Anwas, Pemberdayaan Masyarakat Di Era Global.Bandung, Alfabeta, 2003, pp. 50-65

[10] G.K. Sutawa, "Issues on Bali Tourism Development and Community Empowerment to Support Sustainable Tourism Development" in Proc. 2012 International Conference on Small and Medium Enterprises Development, 2012, pp. 413-422 
[11] https://doi.org/10.1016/s 2212-5671(12)00356-5

[12] L. Lebel. (October 2013). Local knowledge and adaptation to climate change in natural resource-based societies of the Asia-Pacific. Mitigation and Adaptation Strategies for Global Change. [Online]. 18(7). Available: http://link.springer.com/article/10.1007/s11027-012-9407-1

[13] K. Abdullah, A.M. Said and D. Omar. "Community-Based Conservation in Managing Mangrove Rehabilitation in Perak and Selangor" in Proc. 2014 AMER International Conference on Quality of Life, 2014, pp. 121-131

[14] https://doi.org/10.1016/j.sbspro.2014.10.047

[15] B. Chisadza, M. J.Tumbare, W. R. Nyabeze, and I. Nhapi. (June 2015). Linkages between local knowledge drought forecasting indicators and scientific drought forecasting parameters in the Limpopo River Basin in Southern Africa. [Online]. 12. Available: http://www.sciencedirect.com/science/article/pii/S2212420915000102

[16] D. J. Hess. (Winter, 2010). Declarations of Independents: On Local Knowledge and Localist Knowledge. [Online]. 83(1). Available: https://www.jstor.org/stable/i20638694 